\title{
Foraminiferal-based biotic indices to assess the ecological quality status of the Gulf of Gabes (Tunisia): Present limitations and future perspectives
}

\author{
Akram El Kateb $^{\mathrm{a}}$, Claudio Stalder ${ }^{\mathrm{a}, \mathrm{b}}$, Michael Martínez-Colón ${ }^{\mathrm{c}}$, Guillem Mateu-Vicens ${ }^{\mathrm{d}}$, \\ Fabio Francescangeli ${ }^{\mathrm{e}}$, Giovanni Coletti ${ }^{\mathrm{f}}$, Stephanie Stainbank ${ }^{\mathrm{a}}$, Silvia Spezzaferri ${ }^{\mathrm{a}, *}$ \\ ${ }^{a}$ Department of Geosciences, University of Fribourg, Chemin du Musée 6, 1700 CH-1700 Fribourg, Switzerland \\ ${ }^{\mathrm{b}}$ Federal Office of Public Health FOPH, Schwarzenburgstrasse 157, 3003 Bern, Switzerland \\ ${ }^{c}$ School of the Environment, Florida A\&M University, FSH Science Research Center, 1515 South MLK Blvd., Tallahassee, FL 32307, United States \\ 'Cátedra "Guillem Colom Casasnovas," Universitat de les Illes Balears, Cra. de Valldemossa, Km. 7.5, 07122 Palma de Mallorca, Spain \\ e University of Hamburg, Institute for Geology, Centre for Earth System Research and Sustainability, Bundesstraße, 5520146 Hamburg, Germany \\ ${ }^{\mathrm{f}}$ Department of Earth and Environmental Sciences University of Milano-Bicocca, Piazza della Scienza 4, 20126 Milano, Italy
}

A R T I C L E I N F O

\section{Keywords:}

Biotic indices

Mediterranean

Benthic foraminifera

Pollution

Biomonitoring

FOBIMO

Foram-AMBI

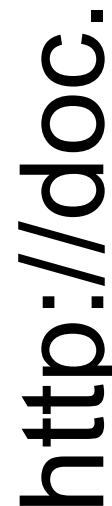

\section{Introduction}

Biotic indices are numerical scales that represent the ecological condition of delimited areas. These indices are based on the fundamental knowledge that changes in the relative abundance of key bioindicator taxa can be applied to monitor not only water quality but also the environmental health of coastal/marine habitats (e.g., Heink and Kowarik, 2010). A key aspect to consider an organism as a bioindicator is that it responds rapidly not only to stress but that its ecological response to environmental changes can effectively be used to monitor current and long-term conditions of the physiochemical characteristics of the water and sediments in coastal/marine areas (e.g., Dale and Beyeler, 2001; Parmar et al., 2016).
The publication of the European Water Framework Directive (WFD, $2000 / 60 / \mathrm{EC}$ ) has prompted the scientific community to propose new and/or apply key existing biotic indices to quantitatively characterize marine soft-bottom habitats based on the ecological quality status (EcoQS) framework (Birk et al., 2012). Although traditionally biotic indices are based on macrofauna (AZTI Marine Biotic Index, AMBI of Borja et al., 2000), more recently microbiomes have been tested (microgAMBI of Aylagas et al., 2017) as environmental health indicators since they are also based on the assemblage ecological response of the coastal/marine benthos along pollution gradients such as organic matter (OM) (Borja et al., 2019).

The coastal/marine benthic environment provides a large array of organisms to be used as bioindicators. For example, meiofaunal

* Corresponding author.

E-mail address: silvia.spezzaferri@unifr.ch (S. Spezzaferri). 
organisms like nematodes are used as bioindicators of pollution based on assemblage composition, maturity level, etc. (Chen et al., 2018). Similarly, for over the past 50 years biotic indices, based on benthic foraminifera, have been increasingly developed and implemented to assess pollution, water quality and changes in environmental conditions (Sen Gupta, 2013). Benthic foraminifera have several advantages as sentinel bioindicator organisms with respect to macrofauna, e.g., they have high density in marine sediments, high species diversity, short life cycle; and their sampling has a low impact on the environment (Hallock et al., 2003; Schönfeld et al., 2012). The FOraminferal BIo-MOnitoring (FOBIMO) initiative developed a standardised method for sampling, storing, processing, and analysing sediment samples for living (stained) benthic foraminiferal assemblages (Schönfeld et al., 2012). The aim of FOBIMO is to simplify the use of benthic foraminifera as a more reliable tool for biomonitoring across ocean basins.

Five biotic indices based on benthic foraminifera are currently used for monitoring soft bottom sediments: (1) Bouchet et al. (2012) proposed the diversity index $\left(\exp \left(\mathrm{H}^{\prime}\right)_{\mathrm{bc}}\right)$ to assess ecological quality status based on the effective number of species derived from living (stained) benthic foraminifera. This index "forecasts" the number of species in a given sample that would be present if each were equally common (e.g., similar $\mathrm{H}_{\mathrm{bc}}$ ). This diversity index was applied to assess the EcoQS in the Norwegian Skagerrak coast (Bouchet et al., 2012), along the Italian coasts (Bouchet et al., 2018; Melis et al., 2019) and to reconstruct the paleoEcoQS in the eastern English Channel (Francescangeli et al., 2016). (2) The Tolerant Species index (\% TS $\mathrm{Tst}_{\text {std }}$ developed by Barras et al. (2014) is based on the relative proportion of stress-tolerant taxa as a function of the grain size $(<63 \mu \mathrm{m})$. It is used in France to distinguish between natural and anthropogenic eutrophication along the coasts of the Gulf of Lion where sediments are characterized by different grain size. The authors follow the definition of eutrophication proposed by - Nixon (1995) as an "increase in the rate of supply of organic matter (OM) to an ecosystem" resulting from nutrient enrichment and the concept of Tyson (1995) that the grain size has a significant impact on the sedimentary organic matter preservation. (3) The Foram Stress Index (FSI), proposed by Dimiza et al. (2016), modelled after the FoRAM-Index of Hallock et al. (2003) and validated with the BENTIX index of Simboura and Zenetos (2002), is based on the relative percentages of two ecological groups of benthic foraminiferal species according to their tolerance/sensitivity to OM enrichment. The FSI is intended to be applied in shallow and non-reefal environments as it was successfully applied in Greece in the Saronikos Gulf, including the industrial polluted zones of Elefsis Bay and of the Port of Piraeus. (4) The "long vs short life span" index ( $\mathrm{I}_{\mathrm{LS}}$ ) and the modified FoRAM-Index (FI') are ephiphytic foraminiferal indices, which can be considered in combination, and are designed to evaluate the ecological status of seagrass dominated meadows of Posidonia oceanica in several locations across the Mediterranean Sea. Developed by Mateu-Vicens et al. (2014), these indices assess the ecological status and conservation of $P$. oceanica meadows by combining the distribution of epiphytic foraminiferal morphotypes of the $\mathrm{I}_{\mathrm{LS}}$ (Table 1) with the water quality and benthic conditions determined by the FI'. (5) The next step of the FOBIMO Initiative is the development of the Foram-AMBI (Alve et al., 2016). Modeled after the AZTI Marine Biotic Index (AMBI) of Borja et al.
(2000), which takes into account the individual species (macroinvertebrates) sensitivity to an environmental stressor, the goal of the Foram-AMBI index is to assess the health of the benthic environments by assigning benthic foraminiferal species to one of five predefined ecological groups according to their tolerance/sensitivity to OM enrichment. This new index has been implemented as a foraminiferal biomonitoring tool for deep-water environments of the North Atlantic (Alve et al., 2016) and in the Mediterranean Sea (Jorissen et al., 2018).

Tunisia is the leading country of phosphate production in the Mediterranean Sea (Fig. 1A). Its 8 million tons/year industrial production (Cisse and Mrabet, 2004) strongly impacts the surrounding marine environments. Three main treatment complexes are located along the Gulf of Gabes. The first production unit was created at Sfax in 1952, followed by the industrial complex of Gabes in 1972 and Skhira in 1988 (Fig. 1B and C). The industrial activities have polluted the surrounding soils and marine sediments (Mkawar et al., 2007; Gargouri et al., 2011; Wali et al., 2013, 2014; Ayadi et al., 2015; El Zrelli et al., 2015) as well as seawater (Darmoul et al., 1980; El Zrelli et al., 2018) with heavy metals and phosphorous. The subsequent pollution has severely impacted the P. oceanica distribution along the Gulf of Gabes. The large meadows reported at the beginning of the 20th century by numerous authors (e.g., Le Danois et al., 1925; Guillaumont et al., 1995; Ben Mustapha et al., 1999; Hattour and Mustapha, 2013; Ben Mustapha and Hattour, 2015) have experienced a 90\% decrease in surface area over the last few decades (Zaouali, 1993; Ben Brahim et al., 2010; El Zrelli et al., 2017). Heavy metal bioaccumulation has been reported in soft tissues of marine fauna (e.g., the gastropod Gibbula ardens and the oyster Pinctada radiata - Messaoudi et al., 2009; Rabaoui et al., 2014) and are responsible for reduced macrobenthic communities (Zaouali, 1993, Pérez-Domingo et al., 2008; El Lakhrach et al., 2012), which could potentially have contributed to coral decline in the central part of the Gulf of Gabes (El Kateb et al., 2016).

Aquatic vegetation has been used as a bioindicator (e.g., P. oceanica) to monitor the effect of pollutants on the coastal environments of the Gulf of Gabes (El Zrelli et al., 2017). Since most of modern epiphytic foraminifera appeared during (or slightly later) the emergence and early expansion of the seagrass environment and they coevolved together with the seagrasses (Pomar et al., 2017), epiphytic foraminiferal assemblages are a potential and valuable indicator of seagrass meadows' health.

Only two investigations were performed using benthic foraminifera to assess the pollution generated by the phosphate industries in Tunisia. One focused on the northern coast of the Gulf of Gabes, around the region of Sfax (Aloulou et al., 2012), and the second focused on the area near the waste discharge in Gabes and the industrial site of Skhira (Ayadi et al., 2016; Fig. 1B and C). These two studies considered the total assemblage (living + dead) of nearshore benthic foraminifera, which renders their interpretations not representative of the ecological status. Total assemblages are time averaged, while living assemblages are more representative of current environmental conditions (e.g., Barras et al., 2014; Alve et al., 2016).

The aim of the present study is to apply and compare for the first time existing benthic foraminiferal biotic indices to assess the impact of phosphate industries at a regional scale, on areas formerly colonized by

Table 1

Classification of the epiphytic foraminiferal morphotypes according to Mateu-Vicens et al. (2014).

\begin{tabular}{|c|c|c|c|}
\hline \multicolumn{3}{|c|}{ Mateu-Vicens et al. (2014) morphotypes (modified after Langer 1993) } & \multirow{2}{*}{$\begin{array}{l}\text { Hallock et al. (2003) } \\
\text { Funtional groups }\end{array}$} \\
\hline Morphotypes & Mobility & Characteristic feature & \\
\hline $\mathrm{A}^{*}$ & Encrusting & Mostly flat forms, permanently attached to the substrate & Symbiont-bearing \\
\hline SB & Sessile & Symbiont-bearing taxa & \\
\hline $\mathrm{B}^{*}$ & Temporary motile & Same as in Langer's (1993) classification & Other heterotrophs \\
\hline $\mathrm{C}^{*}$ & Motile & Same as in Langer's (1993) classification & \\
\hline$D^{*}$ & Permanently motile & Single aperture in upright position & Stress tolerant \\
\hline
\end{tabular}



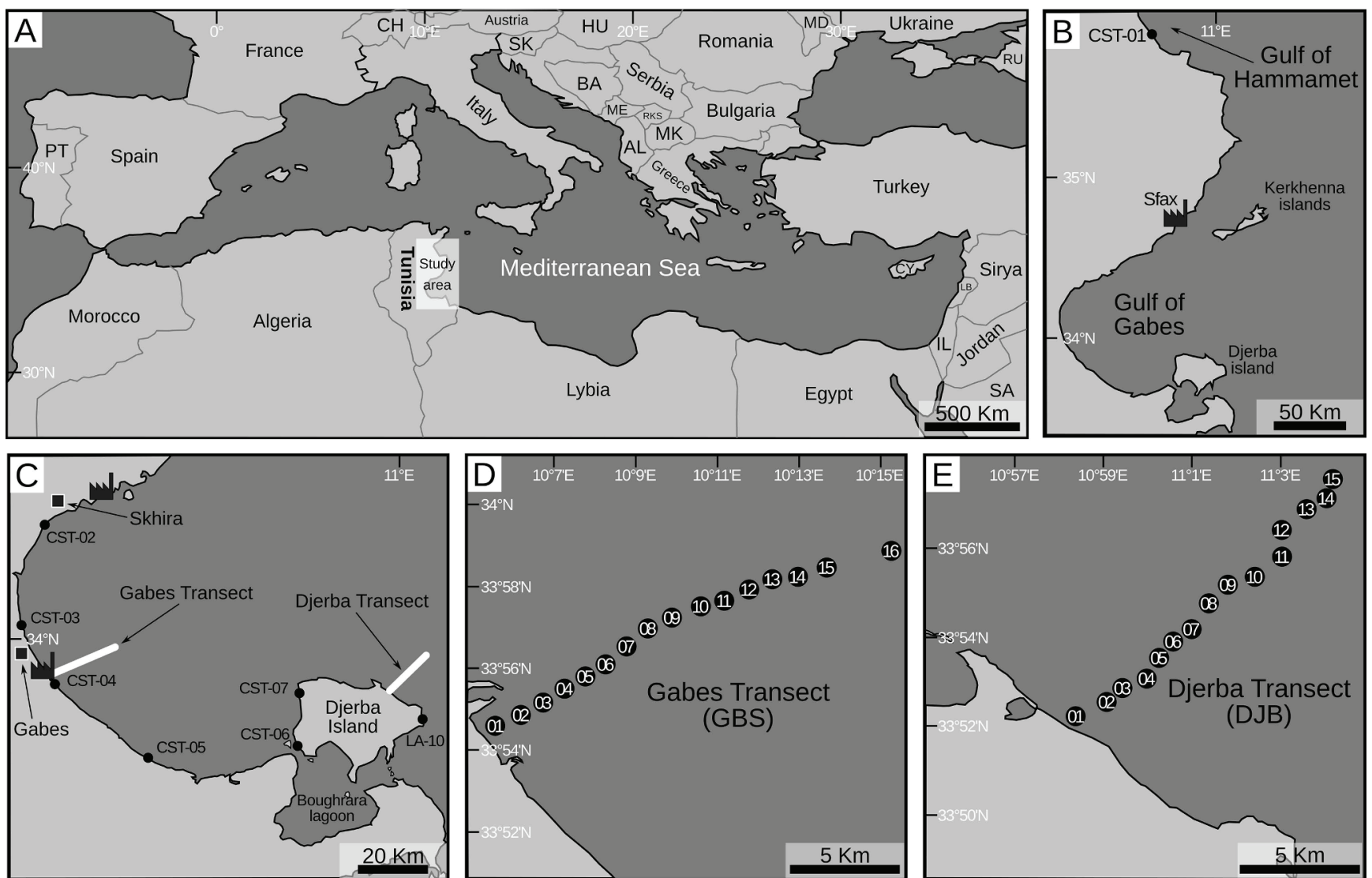

Fig. 1. Location maps of the investigated region. A) The Mediterranean Sea; B) The Gulf of Gabes, the stylized factory indicates the position of the main phosphate industrial complexes; C) Position of the coastal stations, the stylized factories indicate the position of the main phosphate industrial complexes; D) Position of the Gabes transect; E) Position of the Djerba transect.

extensive seagrass meadows, and to test the validity of the ForamAMBI, as well as other indices, for potential future applications in biomonitoring programs in Mediterranean coastal areas.

\section{Hydrological and geographical settings}

The Gulf of Gabes is located in the southern part of Tunisia (Fig. 1B). It is approximatively $90 \mathrm{~km}$ wide, $100 \mathrm{~km}$ long and delimited in the north by the Kerkennah Islands and in the south by the Djerba Island. The tides in this region reach the highest amplitudes of the Mediterranean Sea with a maximum of $2 \mathrm{~m}$ high (Othmani et al., 2017). A gently sloping bathymetry reaches a water depth of $50 \mathrm{~m}$ at around $130 \mathrm{~km}$ from the coastline.

Based on El Zrelli et al. (2018); Ayadi et al. (2015); El Kateb et al. (2018b), two dominant currents prevail in the Gulf: coastal and tidal currents. Tides regulate the flows directed toward land during high tides and toward the open sea during low tides. The Surface Atlantic current has a north-south trend along the Tunisian coast (El-Geziry and Bryden, 2010). However, Othmani et al. (2017) suggests also a southnorth coastal circulation for a large part of the Gulf of Gabes during low and high tides and a main current flowing to the open sea between the Kerkennah and Djerba Islands. This current seems directly related to the tides: during flood tides, the current direction is from the offshore to the coast and vice versa.

\section{Material and methods}

\subsection{Study site, sampling and sample treatment}

Thirty-nine stations were investigated (Fig. 1B-E; Supplementary
Material 1): eight coastal stations were sampled in January 2014, except for Station LA-10, which was sampled in July 2014 (CST-01 to CST-07; Fig. 1B and C); sixteen stations comprise the Gabes transect (GBS-01 to GBS-16; Fig. 1C and D) and fifteen stations the Djerba transect (DJB-01 to DJB-15; Fig. 1C, E), both transects were sampled in July 2014. Along both the Gabes transect and the western coast of Djerba, samples were collected at sites where $P$. oceanica and other seagrasses formed dense canopies until the 80 's and they have progressively disappeared leaving barren substrate due to the anthropogenic pollution (Le Danois et al., 1925; Darmoul, 1988; De Gaillande (1970a,b); Hattour and Ben Mustapha, 2013). Data on living (stained) foraminifera from station LA-10 are from a study of the Djerba Lagoon from El Kateb et al. (2018a). Coastal stations were collected along the shoreline at a shallow depth $(<1 \mathrm{~m})$ and cover $>200 \mathrm{~km}$ of the eastern Tunisian coast (Fig. 1B and C). Djerba and Gabes transects were sampled perpendicularly to the coastline and cover a $17.3 \mathrm{~km}$ and a $13.8 \mathrm{~km}$ long sections, respectively; stations are at approximately $1 \mathrm{~km}$ intervals (Fig. 1D and E) (El Kateb et al., 2018b). Sediment samples from both transects were collected using an Ekman-Birge box core $(15 \times 15 \times 30 \mathrm{~cm})$, which was deployed from a small fishing boat. Sediments from coastal stations were manually collected using plastic containers. The whole sample set was treated following the FOBIMO protocol (Schönfeld et al., 2012). The first centimeter of the surface sediment was collected in plastic bottles and treated with a rose Bengal solution ( $2 \mathrm{~g} / \mathrm{L}$ in alcohol at $90 \%$ ). Living (stained) foraminifera were investigated with a Nikon SMZ18 microscope, picked, counted and stored in plummer cells. Taxonomy at genus and species level follows Cimerman and Langer (1991); Hottinger et al. (1993); Loeblich and Tappan (1994); Milker and Schmiedl (2012). 
Table 2

Threshold values of the biotic indices used in this study.

\begin{tabular}{|c|c|c|c|c|c|c|c|c|c|}
\hline \multicolumn{2}{|c|}{ Epiphytic foraminifera } & \multicolumn{2}{|c|}{ Diversity index } & \multicolumn{2}{|c|}{ Percentage of tolerant species } & \multicolumn{2}{|c|}{ Foram Stress Index } & \multicolumn{2}{|c|}{ Foram-AMBI } \\
\hline \multicolumn{2}{|c|}{ Mateu-Vicens et al. (2014) } & \multicolumn{2}{|c|}{ Bouchet et al. (2018) } & \multicolumn{2}{|c|}{ Barras et al. (2014) } & \multicolumn{2}{|c|}{ Dimiza et al. (2016) } & \multicolumn{2}{|c|}{ Alve et al. (2016) } \\
\hline FI' \& ILS & Ecological status & $\mathrm{H}^{\prime} \mathrm{bc}$ & Ecological status & \%TSstd & Ecological status & FSI & Ecological status & AMBI & Ecological status \\
\hline \multirow[t]{4}{*}{$0-2$} & $\begin{array}{l}\text { Stressed } \\
\text { environment }\end{array}$ & $<3$ & Poor & 100 & $\begin{array}{l}\text { anthropogenic impact } \\
\text { environment }\end{array}$ & 0 & Azoic sediment & $6-7$ & Azoic \\
\hline & & $3-7$ & bad & & & $1-2$ & $\begin{array}{l}\text { Heavily poluted } \\
\text { environment }\end{array}$ & $5.6-6$ & $\begin{array}{l}\text { Heavily polluted } \\
\text { environment }\end{array}$ \\
\hline & & $7-11$ & moderate & & & $2-5.5$ & $\begin{array}{l}\text { Moderately polluted } \\
\text { environment }\end{array}$ & $3.3-5$ & Polluted environment \\
\hline & & $11-15$ & good & & & $5-9$ & $\begin{array}{l}\text { Slightly polluted } \\
\text { environment }\end{array}$ & $1.2-3.3$ & Slightly polluted \\
\hline$>4$ & Optimal condition & $>15$ & excellent & 0 & Pristine environment & $9-10$ & Pristine environment & $0.2-1.2$ & Unpolluted environment \\
\hline
\end{tabular}

\subsection{Benthic foraminifera biotic indices}

Five biotic indices were calculated based on the relative abundances of living (stained) foraminifera categorized into different ecological groups (Tables 1 and 2). Stained foraminifera are here used because they are representative of the assemblages under certain environmental conditions (degrees of pollution) at the time of sampling.

The diversity index of Bouchet et al. (2012) is based on the Shannon-Wiener index $\left(H^{\prime}, \log _{2}\right)$ (Shannon and Weaver, 1963), which expresses the diversity of micro- and macro-fauna. However, since species may be unobserved in the community, H' may be biased due the under-sampling (Chao and Shen, 2003; Bouchet et al., 2012). Therefore, the correction of Shannon's index $\left(\mathrm{H}_{\mathrm{bc}}^{\prime}\right)$ proposed by Chao and Shen (2003) is applied in order to provide true diversity (effective number of species) as an exponential function of $\mathrm{H}_{\mathrm{bc}}^{\prime}$. Hence the index is expressed by the Eq. (1):

$\exp \left(\mathbf{H}^{\prime}\right)_{\mathbf{b c}}$ (see Bouchet et al., 2012 for further details)

The EcoQS classes developed for the Italian coastal environments by Bouchet et al. (2018) are applied in this study based on their geographical proximity to the Gulf of Gabes. Five different EcoQS classes based on diversity index values are defined from poor $(<3)$ to excellent (> 15) (Table 2).

The \% $\mathrm{TS}_{\text {std }}$ index (Barras et al., 2014) assumes a calculated standardized percentage of stress-tolerant species taking into consideration the percentage of samples with a mean grain-size $<63 \mu \mathrm{m}$. This index is defined by the following Eq. (2):

$\% T S_{\text {std }}=\left[\left(T S_{x}-\% T S_{r e f}\right) /\left(100-\% T S_{\text {ref }}\right)\right] * 100$ (see Barras et al., 2014 for further details)

where $\% \mathrm{TS}_{\mathrm{x}}$ is the percentage of tolerant species and $\% \mathrm{TS}_{\text {ref }}$ is the

Foram $-A M B I=[(0 * \% G I)+(1.5 * \% G I I)+(3 * \% G I I I)+(4.5 * \% G I V)+(6 *$

theoretical percentage of tolerant species. "Stress-tolerant" species are those very abundant in stressed conditions, such as eutrophication or when there is a significant supply of fine-grained sediments. $\% \mathrm{TS}_{\text {std }}$ values close to $0 \%$ should indicate pristine and healthy environments and values close to $100 \%$ should indicate impacted environments (Table 2). Due to the presence of a few tolerant species in our study sites, as proposed by Barras et al. (2014), the \%TS std was calculated using the ecological groups of the FSI (Dimiza et al., 2016) coupled with those species assigned to ecological groups in the Mediterranean Sea (Jorissen et al., 2018). We assume that the stress-tolerant (Str) in Dimiza et al. (2016) are represented by the sum of \%GIII (species tolerant to excess OM enrichment), \%GIV (second order opportunistic species) and \%GV (first-order opportunistic species) of Jorissen et al. (2018), which correspond to the $\mathrm{TS}_{\mathrm{x}}$ in Barras et al. (2014).

The FSI (Dimiza et al., 2016) is based on the relative percentage of two ecological groups: sensitive (Sen) and stress-tolerant (Str) and is calculated following the Eq. (3):
$F S I=(10 * S e n)+($ Str $) \quad($ see Dimiza et al., 2016 for further details $)$

The FSI ranges from 0 (azoic sediments) to 10 (pristine environments) (Table 2).

To investigate the environmental conditions of ecosystems that naturally would be colonized by meadows of $P$. oceanica and other seagrass species, the $\mathrm{FI}^{\prime}$ and $\mathrm{I}_{\mathrm{LS}}$ epiphytic foraminiferal indices of Mateu-Vicens et al. (2014), based on five foraminiferal morphotypes (Table 1), were used. For comparing the FI' and $\mathrm{I}_{\mathrm{LS}}$ with the FoRAM Index (see Hallock et al., 2003; modified slightly by Carnahan et al., 2009) we assumed the same ecological distinctions that the symbiontbearing and sensitive taxa are represented by the morphotypes SB and $\mathrm{A}^{*}$; stress-tolerant species correspond to the morphotype $\mathrm{D}^{*}$; and the heterotrophic species are represented by $\mathrm{B}^{*}$ and $\mathrm{C}^{*}$ morphotypes (Table 1). The FI' and $\mathrm{I}_{\mathrm{LS}}$ are defined by the following two Eqs. (4-5):

$F I^{\prime}=10 *\left(P_{A *}+P_{S B}\right)+P_{D *}+2 *\left(P_{B}+P_{C}\right)$

$\mathrm{I}_{\mathrm{LS}}=\left(3.5 *\left(\mathrm{P}_{\mathrm{A} *}+\mathrm{P}_{\mathrm{SB}}\right)+0.1\right) /\left(\mathrm{P}_{\mathrm{D} *}+0.1\right)$

(see Table 1 and Mateu-Vicens et al., 2014 for further details)

For both indices, values above 4 indicate optimal conditions while values lower than 2 indicate stressed conditions (Table 2). The $\mathrm{I}_{\mathrm{LS}}$ is conceived to magnify the difference between well preserved and stressed environments of $P$. oceanica meadows.

For the Foram-AMBI, benthic foraminiferal species attribution into five ecological groups are defined based on their response to OM enrichment (Alve et al., 2016; Jorissen et al., 2018). GI) Very sensitive species; GII) Indifferent species; GIII) Tolerant species ; GIV) Second order opportunistic and GV) First-order opportunistic species. This index is expressed by the following Eq. (6):

$\% G V)] / 100$ (see Alve et al. , 2016 and Jorissen et al. , 2018 for further details)

The index ranges from 0 (unpolluted) to 7 (azoic) reflecting the degree of pollution (Table 2).

\subsection{Statistical treatment}

A Principal Component Analysis (PCA) was carried out to highlight discrete relationships between the environmental variables and biotic indices (Fig. 2). Except for species richness (S), the data on TOC (Total Organic Carbon), grain-size, total phosphorous, and heavy metal concentrations in the sea water are from El Kateb (2018) and El Kateb et al. (2018b) (Supplementary Material 2). A unit variance scaling (Autoscaling) was adopted as the data pre-treatment approach. The data for each variable was mean-centered and then divided by the standard deviation of the variable. For the analysis, the following variables were considered: grain-size (mud and sand), TOC, $\mathrm{P}_{\text {tot }}, \mathrm{C} / \mathrm{N}$ and metals (As, $\mathrm{Cd}, \mathrm{Cu}, \mathrm{Ni}, \mathrm{Fe}, \mathrm{Cr}, \mathrm{Li}, \mathrm{Pb}, \mathrm{Zn}, \mathrm{P}$ ). The measurements of these variables were used, as they were available for all sampling stations along Gabes 


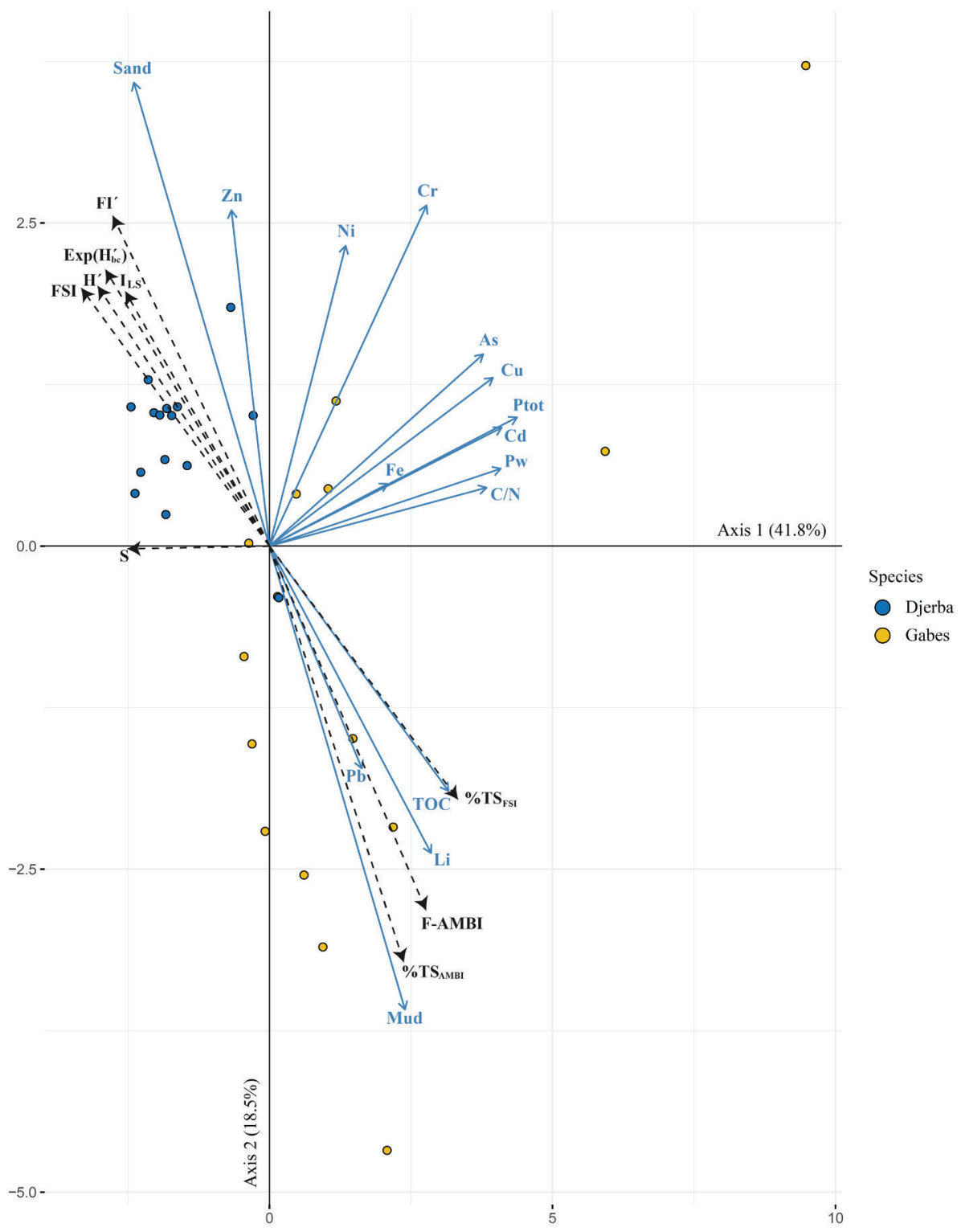

Fig. 2. Principal Component Analysis (PCA) plot to visualize the associations between pollutants and biotic indices.

and Djerba transects. The biotic foraminiferal-based indices were plotted as supplementary variables. Supplementary variables were not used to calculate the principal components. The $\mathrm{R}$ software ( $\mathrm{R}$ Core Team, 2018) was used for statistical computing and graphics, by using the following packages: FactoMineR (Husson et al., 2019), factoextra (Kassambra and Mundt, 2017), corrplot (Wei et al., 2017). A draftsman plot was used to highlight and validate the associations between the environmental variables and the biotic indices (Supplementary Material 3).

\section{Results}

One hundred and sixty-three species were identified and 6887 living (stained) specimens were counted. Species abundances and assemblage composition for each sample are in Supplementary Material 4.

The lowest species richness ( $\mathrm{S}$ ) along the Gabes transect is recorded at station GBS-01 (5 species) and the highest at stations GBS-12 and 13 (37 species). Samples from station GBS-03 are devoid of benthic foraminifera (0 species). Species richness is remarkably higher along the Djerba transect with $S$ values fluctuating from 21 (DJB-21) to 48 (DJB12). Forthy-eight species are also documented in station LA-10B, whereas S varies from 12 (CST-2) to 25 (CTS-05) among the other coastal stations (Table 3).

Variations in the $\mathrm{H}^{\prime}\left(\log _{2}\right)$ diversity index range from 1.2 (GBS-09) to 3.8 (GBS-12) along the Gabes transect and from 1.69 (DJS-01) to 4.4 (DJB-05, DJB-11 and DJB-12) along the Djerba transect (Table 3).

At station LA-10B, $\mathrm{H}^{\prime}\left(\log _{2}\right)$ is 4.4 , and among the other coastal stations it varies from 2.3 (CTS-07) to 3.6 (CTS-02).

The $\exp \left(H^{\prime}\right)_{b c}$ varies from 3 to 16 along the Gabes transect, from 3 to 24 along the Djerba transect and from 6 to 19 along the coastal stations and has a value of 8 at LA-10B (Table 3; Fig. 3).

The standardized percentage of tolerant species ( $\left.\% \mathrm{TS}_{\text {std }}\right)$ for FSI and Foram-AMBI are significantly higher along the Gabes transect than Djerba transect, especially in their distal parts (Table 3; Fig. 3). From GBS-07 to GBS-16, the standardized percentage of tolerant species varies between 63.2 and $100 \%$ (Foram-AMBI assigned species) (Table 3; Fig. 3). Along the distal part of the Djerba transect (from DJB04 to DJB-15) the standardized percentage of tolerant species never exceeds $42 \%$ (Table 3; Fig. 3). At LA-10B the values are of 6.7 (FSI assigned species) and 5.1 (Foram-AMBI assigned species) (Table 3).

The epiphytic foraminiferal indices (FI' and $\mathrm{I}_{\mathrm{LS}}$ ) vary significantly between the Gabes and Djerba transects and coastal stations (Table 3; 


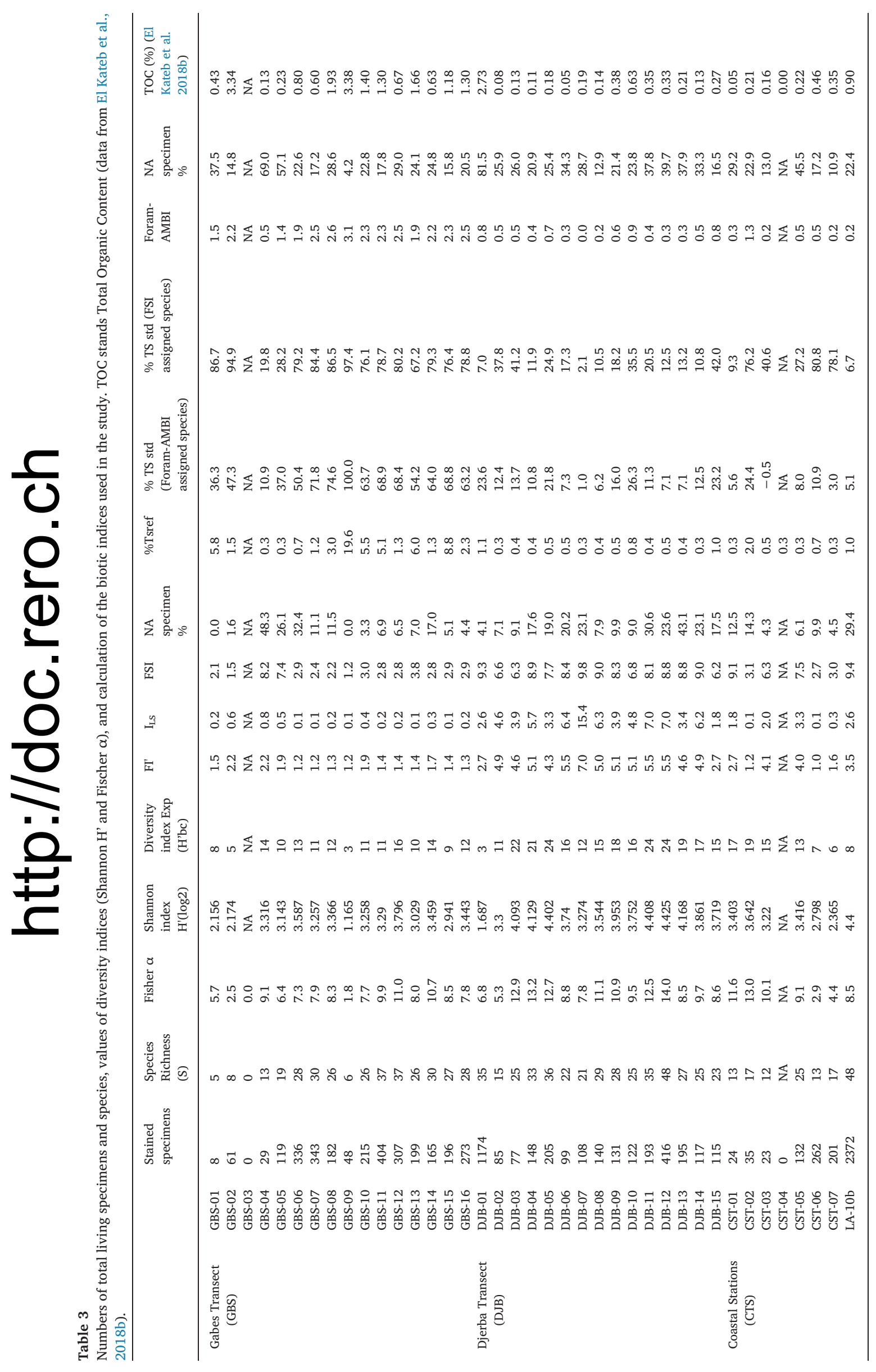


Shannon Index (H')

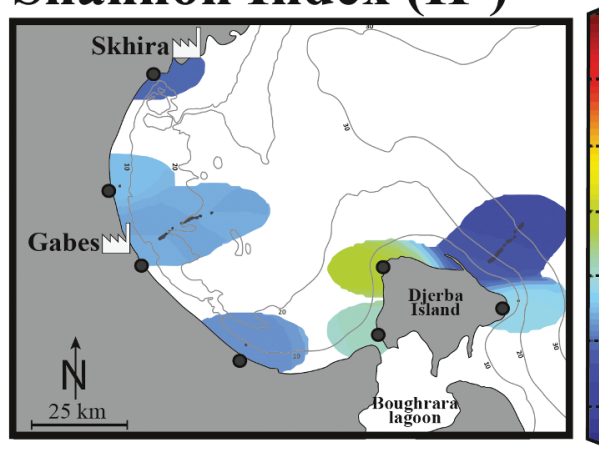

FI'

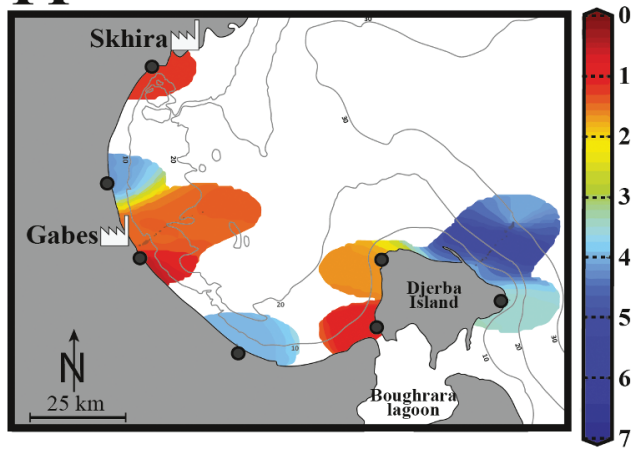

FSI

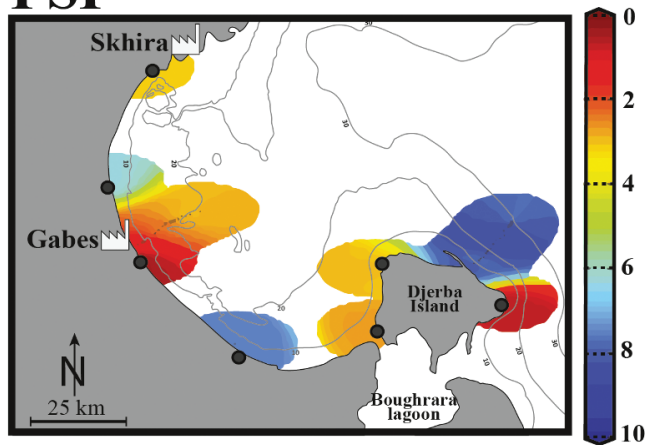

Foram-AMBI

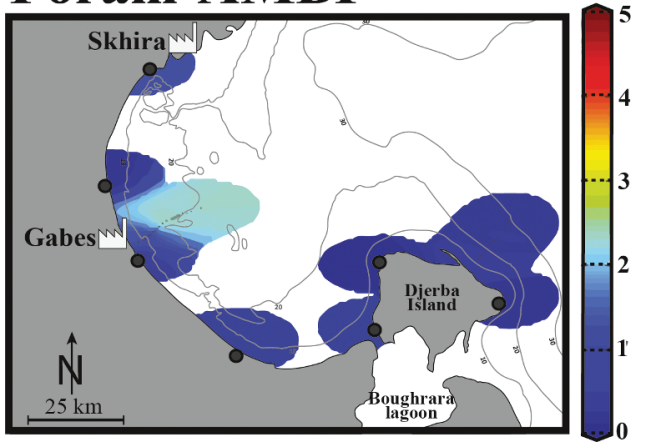

$\operatorname{Exp} \mathbf{H}_{\mathbf{b c}}$

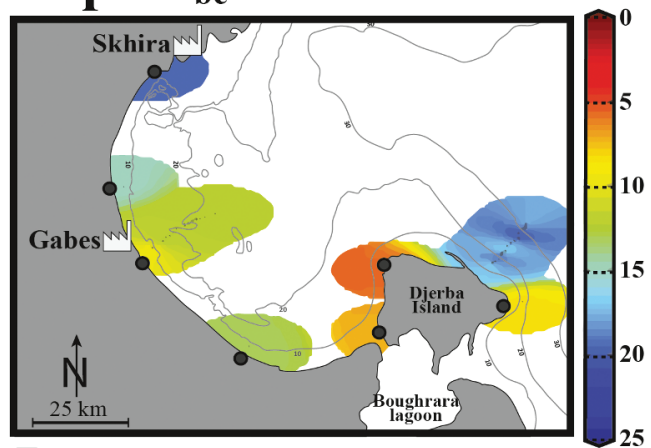

$\mathbf{I}_{\mathrm{LS}}$

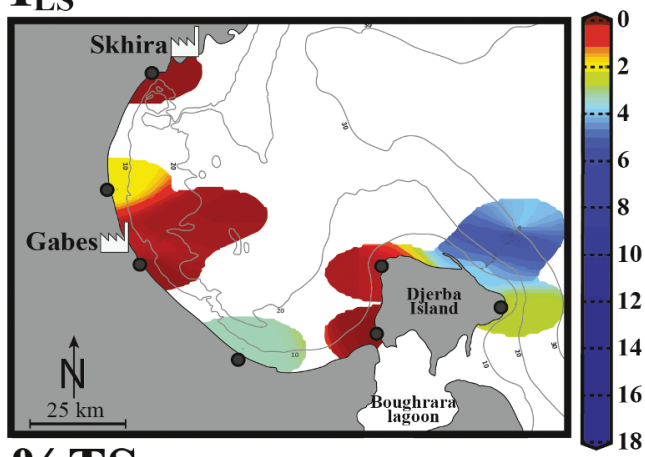

\% TS

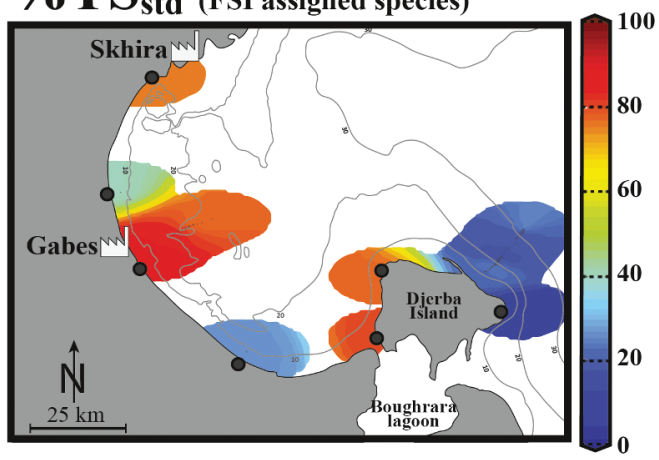

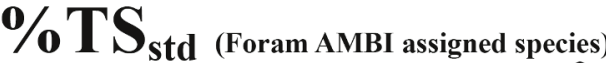

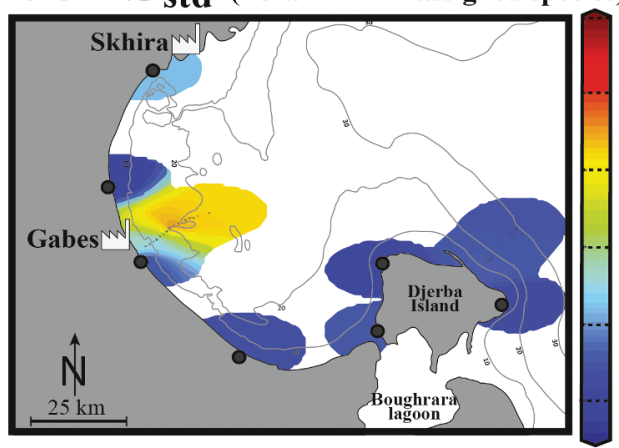

Fig. 3. Graphical representation of the ecological quality status in the Gulf of Gabes. Data are spatially interpolated with the DIVA software tool (Data-Interpolating Variational Analysis, Troupin et al., 2012).

Fig. 3). The FI' values were the lowest along the Gabes transect ranging from 1.2 (GBS-06/07) to 2.2 (GBS-02/04) followed by the coastal stations CST-06 and CST-03 with values ranging from 1 to 4.1, respectively. The Djerba transect had the highest values overall, ranging from 2.7 (DJB-01/15) to 7 (DJB-07), whereas at LA-10B it is 3.5 (Table 3; Fig. 3). Differences in $I_{L S}$ values between the Gabes and Djerba transects are also remarkable (Table 3; Fig. 3). They fluctuate between 0.1 (GBS06/07/09/13/14) and 0.8 (GBS-04) at Gabes and from 1.8 (DJB-15) to
15.4 (DJB-07) at Djerba. The $\mathrm{I}_{\mathrm{LS}}$ values vary from 0.1 (CST-02/06) to 3.3 (CST-05) at the coastal stations and is 2.6 at LA-10B (Table 3; Fig. 3).

The values of FSI do not exceed 8.2 (GBS-04) along the Gabes transect with a minimum value of 1.2 (GBS-09) while along the Djerba transect they vary from 6.2 (DJB-15) to a maximum of 9.8 (DJB-07) (Table 3; Fig. 3). The coastal stations have FSI values between 2.7 (CST06) and 9.4 (LA-10B) (Table 3; Fig. 3). 
The Foram-AMBI values along the Gabes transect are slightly higher than the values from the Djerba transect and coastal sites (Table 3; Fig. 3). They fluctuate from 0.5 (GBS-04) to 3.1 (GBS-09) along the Gabes transect, however, they never exceed 0.9 (DJB-10) along the Djerba transect. The Foram-AMBI varies from 0.2 to 1.3 at the coastal stations, and is 0.2 at LA-10B (Table 3; Fig. 3).

There were in total 18 Eigen values in the PCA. The first two axes account for $60.3 \%$ of the total variance $(41.8 \%$ and $18.5 \%$ respectively) (Fig. 2). All variables are well represented by the first two dimensions except for Fe, Ni, Pb and Zn (Fig. 2). As, Cd, Cu, Cr, Li, TOC, $\mathrm{P}_{\text {tot }}$ and C/ $\mathrm{N}$ contribute to the first axis while Grain-size (sand and mud), mostly, to the second (Fig. 2). All the variables (except for $\mathrm{Zn}$ and Sand) are placed at the right of the first axis. The majority of the sampling stations from the Gabes and Djerba transects show positive and negative association to the first axis, respectively. Whereas on the contrary, the Djerba and Gabes transects show positive and negative association to the second axis, respectively (Fig. 2).

\section{Discussion}

The inner part of the Gulf of Gabes is presently affected by intense pollution and the adverse ecological conditions for marine life are extensively documented (e.g., El Kateb, 2018; El Kateb et al., 2018b, and references therein). For this reason, the Gabes transect, positioned within the Gulf of Gabes, was sampled for a direct comparison with the Djerba transect (eastern coast), which was chosen to possibly represent a more "pristine" environment. The most commonly used biotic indices, based on benthic foraminifera, are tested in the present study to prove their reliability in biomonitoring studies in this region (Fig. 3).

\subsection{Geographical distribution of ecological impacts}

\subsubsection{Gabes}

At Gabes, the industrial waste (wastewater, phosphogypsum and sludge) is directly discharged into the Sea. Consequences of this practice, since the 1970s, are seawater acidification, high concentrations of phosphorus and fluorine and sea floor siltation (Darmoul et al., 1980; Zaouali, 1993; El Lakhrach et al., 2012). This are responsible for the decline of $P$. oceanica meadows in the Gulf of Gabes (Ben Brahim et al., 2010). Factors such as surface ocean circulation (Guetat et al., 2012), types of contaminants (e.g., El Zrelli et al., 2018), and substrate (Zaouali, 1993) among others, impact the Gulf at different levels. Several investigations report high concentrations of heavy metals in marine sediments and in the seawater surrounding the Gabes industrial site (Darmoul et al., 1980; Ayadi et al., 2015; El Zrelli et al., 2015, 2018; Ayadi et al., 2016; El Kateb et al., 2018b). Of the heavy metals released into the inner section of the Gulf of Gabes, zinc, copper, mercury and lead have the highest concentrations ever documented in any marine environment in Tunisia (Chouba and Mzoughi-Aguir, 2006; Aloulou et al., 2012; Kharroubi et al., 2012a,b; Ayadi et al., 2015). However, most of these studies only investigated nearshore environments while a few limited studies analysed the offshore sediments in the central part of the Gulf of Gabes.

As expected, the FI' and $\mathrm{I}_{\mathrm{LS}}$ epiphytic foraminiferal indices, \% $\mathrm{TS}_{\text {std }}$ (FSI assigned species) and the FSI indicate adverse ecological conditions in the Gulf of Gabes and for the seagrass meadows that once occupied most of the area (Tables 2 and 3; Fig. 3). This new information suggests that these indices correctly reflect the ecological status of the marine environment and corroborate previously published data on pollution. On the contrary, the level of impact determined by the $\exp \left(\mathrm{H}^{\prime}\right)_{\mathrm{bc}}$,

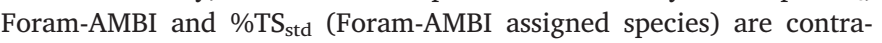
dictory, suggesting that the overall ecological status is unpolluted to slightly-moderately polluted in this region (Tables 2 and 3; Fig. 3).

\subsubsection{Djerba Island and Skhira}

The western coast of Djerba Island has been investigated less in comparison to the central coast of the Gulf of Gabes and the pollution-related studies are scarce. Along these coasts, as in other areas of the Gulf of Gabes, $P$. oceanica meadows have retreated considerably since early $\mathrm{XX}^{\text {th }}$ century and mostly during the last decades, due to anthropogenic activities.

The high phosphorous content in the seawater along the western coast of the island (Guetat et al., 2012) suggests that this region may also be influenced by the Gabes phosphate industry due to surface circulation. Heavy metals contamination in surface sediment from the Boughrara lagoon, which is directly connected with the western coast of Djerba, are reported in Ben Aoun et al. (2007) and Kharroubi et al., 2012a,b). The provenance of these contaminants may be also linked to the phosphate industry pollution transported off-shore by tidal currents.

Based on the biotic indices FI', $\mathrm{I}_{\mathrm{LS}}, \mathrm{FSI}$ and \% $\mathrm{TS}_{\text {std }}$ (FSI assigned species), the ecological conditions along the western coasts of Djerba Island seem to be impacted, similarly to Gabes, although to a lower degree (Tables 2 and 3; Fig. 3). Conflicting results were obtained from

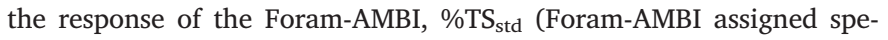
cies), and the $\exp \left(\mathrm{H}^{\prime}\right)_{\mathrm{bc}}$. The latter index suggests that the marine environment has been negatively impacted, while the former two suggests that it is unpolluted. The sites along the eastern coast of Djerba Island (Djerba transect) have been chosen for a direct comparison with the heavily polluted Gulf of Gabes and are considered as remarkably less impacted. Indeed all applied biotic indices confirm this hypothesis.

Although a phosphate treatment complex is present at Skhira, the management practices of the waste product (i.e. phosphogypsum) are more environmentally conscious when compared to Gabes. Phosphogypsum wastes are stored on land forming large stacks surrounded by dams and basins that control the water runoff in order to minimize contamination of the marine environment (GEREPEnvironment, 2007). However, despite these environmental management practices, heavy metal contamination of marine sediments has been reported around the industrial site (Aloulou et al., 2012; Ayadi et al., 2016). Additionally, this complex requires large quantities of industrial fresh water to run the phosphate processing treatment. Seawater desalination assures fresh water availability (GEREPEnvironment, 2007) without compromising the aquifers, which are rare in this region (e.g. Ben Alaya et al., 2014; Chandoul et al., 2015). Desalination produces brackish water, which is discharged into the sea (GEREP-Environment, 2007) and therefore, is impacting the environment (Einav et al., 2003) by significantly decreasing the salinity, leading to a reduction in seagrass habitat (i.e., P. oceanica) (FernándezTorquemada and Sánchez-Lizaso, 2005; Gacia et al., 2007). Brackish waters, as desalination byproducts, also influence the density of subtropical living benthic foraminifera (Chesher, 1975). Similarly, ecological responses of stress-sensitive benthic foraminifera to brackish water were observed in the Djerba lagoon, on the eastern coast by (El Kateb et al., 2018a). The FI', $\mathrm{I}_{\mathrm{LS}}$, FSI and \% $\mathrm{TS}_{\text {std }}$ (FSI assigned species), show impacted environment while the Foram-AMBI, \%TS std (ForamAMBI assigned species), and the exp $\left(\mathrm{H}^{\prime}\right)_{\mathrm{bc}}$ show good ecological conditions at Skhira (Tables 2 and 3; Fig. 3).

\subsection{Epiphytic foraminifera vs. Posidonia oceanica in the Gulf of Gabes}

The importance of preserving $P$. oceanica seagrass meadows has recently been stressed by the IUCN (International Union for Conservation of Nature), highlighting the role of their ecosystemic services (Pergent et al., 2016). In particular, the IUCN "red list of threatened species" stresses that $P$. oceanica populations along the Mediterranean Sea coasts are currently decreasing mainly due to anthropogenic activities. This plant, endemic of the Mediterranean Sea, is very sensitive to environmental variability, and for this reason is a good indicator of the ecosystem's health. The cover area of this seagrass species can vary through time (few months to few years), depending on multiple stress factors (e.g. anthropogenic pressure), that consequently affects benthic foraminiferal populations on a short time scale (days to weeks).

There are protocols to directly assess the environmental state of 
seagrass meadows (e.g. POMI - Romero et al., 2007) that are expensive and time consuming. However, the use of epiphytic foraminifera has proven to be advantageous in terms of reliability and low economical cost. The FI' and $\mathrm{I}_{\mathrm{LS}}$ show stressed environments in a large part of the Gulf of Gabes (Tables 2 and 3; Fig. 3), which are no longer suitable for seagrass growth in contrast with previous decades. For example, noticeable variations in $P$. oceanica coverage in the Gulf of Gabes are limited to their proximity to the industrial waste discharge effluents at Gabes (Darmoul et al., 1980). A recent study on $P$. oceanica meadows in the Gulf of Gabes documents a significant decrease in cover post 1970 (El Zrelli et al., 2017). The epiphytic foraminiferal indices reflect well the current environmental conditions for $P$. oceanica in the same area (from CST-03 to CST-05). As expected, station CST-04 which is in proximity to the industrial effluents is completely devoid of $P$. oceanica meadows (El Zrelli et al., 2017) and the FI' and $\mathrm{I}_{\mathrm{LS}}$ indices values reflect conditions unsuitable for its growth (Tables 2 and 3; Figs. 1, 3). Similarly, at Stations CST-03 and CST-05, where seagrass meadows are present and form littoral belt and/or patches (El Zrelli et al., 2017), both indices indicate favorable ecological conditions suitable for growth and seagrass establishment (Tables 2 and 3; Figs. 1, 3). Along the Gabes transect $P$. oceanica totally disappeared (Zaouali, 1993; El Kateb et al., 2016; El Kateb et al., 2018b) and the indices reflect the lowest values indicative of unsuitable growth conditions (Tables 2 nd 3; Fig. 3). The same indices show optimal conditions for growth along the Djerba transect, where $P$. oceanica forms large meadows (El Kateb et al., 2018b) (Tables 2 and 3; Figs. 1, 3). The distribution of $P$. oceanica has never been described along the western coast of Djerba Island (CST-06 and CST-07); close to the Skhira phosphate industry (CST-02) and in the Gulf of Hammamet (CST-01) (Fig. 1). The low epiphytic index values close to Skhira (Fig. 3) certainly reflect unfavorable conditions associated with extensive industrial activity and subsequent contamination of surface sediment with heavy metals (Aloulou et al., 2012; Ayadi et al., 2016). Although no information is available on the environmental condition also in the Gulf of Hammamet, $P$. oceanica meadows are relatively well established (El Kateb, pers. observ.). In this area, the intense tourism seems to not have a major effect on the nearshore environment and may even contribute to the protection of the marine coastal environment. This is also the case for the Djerba transect where the ecological conditions are considered as optimal (El Kateb et al., 2018b; Tables 2 and 3; Fig. 3).

\section{.3. Validation of results}

Of all the ecological signals given by the indices used in this study, the FI' and $\mathrm{I}_{\mathrm{LS}}$ epiphytic foraminiferal indices coupled with $\% \mathrm{TS}_{\text {std }}$ and FSI reflect maximum ecological impact, while the $\exp \left(\mathrm{H}^{\prime}\right)_{\mathrm{bc}}$ and the coupled Foram-AMBI and \% $\mathrm{TS}_{\text {std }}$ (Foram-AMBI assigned species), respectively reflect lower environmental ecological status and pristine conditions (Tables 2 and 3; Fig. 3).

In order to test the results, a PCA plot was obtained to show possible discrete relationships between pollutants and biotic indices (Fig. 2). This plot shows that the majority of the Gabes samples positively associate with a higher muddy sediment fraction, TOC, total phosphorus and heavy metal concentrations in the sea water. Additionally, there is a relation with the Foram-AMBI and \%TS indices. In general, OM content is associated to the smaller sediment size fractions, from mud to silt (e.g., Ackermann et al., 1983; Bergamaschi et al, 1997; Lakhan et al., 2003; Andrieux-Loyer and Aminot, 2001). In these sediments, opportunistic/stress tolerant benthic foraminiferal species are also dominant (e.g., Alve et al., 2016; Jorissen et al., 2018). As both indices are based on the abundances of more sensitive versus opportunistic species this would explain the link between the Foram-AMBI and the \%TS indices at Gabes, which is characterized by intense sea floor siltation. The positive association of the Foram-AMBI and the \%TS indices with pollutants such as $\mathrm{Pb}$ and Li can be explained by the proximity of the Gabes stations to the pollution source (industrial complex, Fig. 1).
Djerba transect samples on the contrary, appear to positively associate with higher values in the coarser sediment fraction (sand), of the epiphytic indices and the FSI, together with higher concentrations of $\mathrm{Zn}$ in sea water as the only pollutant, although as stated $\mathrm{Zn}$ is not entirely represented by the first two PCA axes. Coarser sediments were indeed recovered along the Djerba transect (Supplementary Material 2). Furthermore, along this transect $P$. oceanica meadows are still present (El Kateb et al., 2018b), which further supports the link with the epiphytic indices as they are based on species living attached to Posidonia. The association of the Djerba stations to high Zn concentrations deserves some comment. Zinc has been identified as the most abundant heavy metal in the Gulf of Gabes in sediments recovered in front of the industrial complex (El Zrelli et al., 2015). Yet, elevated Zn concentrations were not documented in the seawater along the Gabes transect in El Kateb (2018) (Supplementary Material 2). Zinc precipitation and migration into the sediments may account for these low concentrations in the seawater (Ayadi et al., 2015), and this hypothesis is further supported by the documentation of sphalerite near the industrial complex (El Kateb et al., 2018b). Along the Djerba transect, Zn concentrations in seawater (from 14 to $104 \mu \mathrm{g} / \mathrm{L}$ ) are generally higher (Supplementary Material 2) than the usual Zn concentrations in seawater ranging from 0.4 to $5 \mu \mathrm{g} / \mathrm{L}$ (Moore and Ramamoorthy, 1984). Two processes may account for this discrepancy, firstly $\mathrm{Zn}$ may be transported by currents flowing from the coast to offshore during low tides (Othmani et al., 2017) or alternatively decaying plankton may be releasing $\mathrm{Zn}$ in the seawater (Moore and Ramamoorthy, 1984). This latter hypothesis is favoured since it is supported by stable carbon isotopic composition of sedimentary organic matter from the distal part of the Gabes transect, reflecting a high abundance of marine phytoplankton-derived organic matter (El Kateb et al., 2018b).

\subsection{Foram-AMBI and its presently underestimated ecological condition}

The recently proposed Foram-AMBI reflects changes in environmental disturbances along a gradient of increased organic matter (Alve et al., 2016; Jorissen et al., 2018). Organic matter has been chosen to develop the Foram- AMBI since its presence and abundance is related to mud content in sediments, it impacts dissolved oxygen and, more importantly, pollutants like heavy metals and polychlorinated biphenyls (PCBs) strongly associate with organic matter (Milliman, 1994; Schorer, 1997; Bergamaschi et al., 1997; Martínez-Colón et al., 2009; Alegría et al., 2016). Indeed an organic matter trend is observed in the Gulf of Gabes (El Kateb et al., 2018b). However, the actual application of the Foram-AMBI, in the investigated region, presents some limitations. In particular, the Foram-AMBI values obtained for the area surrounding the industrial waste discharge at Gabes and Skhira indicate that these environments are only slightly polluted, compared to other indices showing heavily polluted conditions (Tables 2, 3; Fig. 3). The highest Foram-AMBI values are obtained from the distal section of the Gabes transect (Table 3; Fig. 3), which is especially affected by the industrial pollution and is rich in TOC (El-Kateb et al., 2018b).

In this study the correlation between the Foram-AMBI with TOC and all other pollutants (Supplementary Material 3) suggests that the Foram-AMBI, as it is presently applied, does not properly reflect EcoQS, as the AMBI of Borja et al. (2000) does for macrofauna. Similarly to Alve et al. (2016), the applied equation and coefficients proposed by Borja et al. (2000) for benthic macrofauna where implemented here for living (stained) benthic foraminifera. Adapted coefficients and/or a modification of the Borja et al. (2000) equation may better represent the real ecological status. Therefore, additional work to produce weighted coefficients for benthic foraminifera is necessary. In addition, several samples have low foraminiferal densities of living specimens, which limits species assignment to ecological groups (Alve et al., 2016; Jorissen et al., 2018). In this study $64 \%$ of the samples exceeded the $20 \%$ threshold of unassigned species, which invalidates the proper use and effectiveness of the Foram-AMBI (Supplementary Material 4). 


\section{Conclusions}

The biotic indices FI' and $\mathrm{I}_{\mathrm{LS}}, \% \mathrm{TS}_{\text {std }}$ and FSI, and $\exp \left(\mathrm{H}_{\mathrm{bc}}{ }^{\prime}\right)$, based on living foraminiferal assemblages, reflect highly impacted environments in a large part in the Gulf of Gabes due to the pollution by the phosphate industries. The indices indicate that the most impacted areas are the central part of the Gulf, the western coast of Djerba Island and the regions surrounding the Skhira phosphate industry, confirming direct observations and geochemical data. This pollution has severely affected the $P$. oceanica meadows in the Gulf of Gabes and is expressed by low epiphytic foraminiferal indices (FI' and $\mathrm{I}_{\mathrm{LS}}$ ) values, which seem to be the best indices to apply in this region. The application of the recently developed Foram-AMBI is presently not appropriate to assess the ecological conditions in the Gulf of Gabes since a large percentage of the present species are not assigned to ecological groups. Before its routine application in biomonitoring, additional studies are needed to increase the number of species assigned to ecological groups and to adapt the coefficients in the Foram-AMBI equation to foraminiferal assemblages. However, this index as it is, reflects relatively well the sedimentary organic matter distribution within the Gulf of Gabes.

\section{Credit authorship contribution statement}

Akram El Kateb: Investigation, Methodology, Conceptualization, Visualization. Claudio Stalder: Resources, Conceptualization. Michael Martínez-Colón: Conceptualization, Writing - review \& editing. Guillem Mateu-Vicens: Conceptualization, Writing - review \& editing. Fabio Francescangeli: Formal analysis, Writing - review \& editing. Giovanni Coletti: Visualization, Writing - review \& editing. Stephanie Stainbank: Formal analysis, Writing - review \& editing. Silvia Spezzaferri: Supervision, Funding acquisition, Resources, - Conceptualization, Writing - review \& editing.

\section{Acknowledgments}

We are very grateful to Kamel El Kateb, who greatly helped during the organization of the field work in the Gulf of Gabes. Thanks to the FOBIMO members for the fruitful discussions about biotic indices. We acknowledge the reviewers for their valuable comments that help to improve considerably this manuscript. This research was supported by the Swiss National Science Foundation grant 200021_149589.

\section{Appendix A. Supplementary data}

Supplementary data to this article can be found online at https:// doi.org/10.1016/j.ecolind.2019.105962.

\section{References}

Ackermann, F., Bergmann, H., Schleichert, U., 1983. Monitoring of heavy metals in coastal and estuarine sediments-a question of grain-size: $<20 \mu \mathrm{m}$ versus $<60 \mu \mathrm{m}$. Environ. Technol. 4, 317-328.

Alegría, H., Martínez-Colón, M., Kurt-Karakus, P., Brooks, G., Hanson, L., Birgul, A., 2016. Historical sediment record and levels of PCBs in sediments and mangroves of Jobos Bay, Puerto Rico. Sci. Total Environ. 573, 1003-1009.

Aloulou, F., EllEuch, B., Kallel, M., 2012. Benthic foraminiferal assemblages as pollution proxies in the northern coast of Gabes Gulf, Tunisia. Environ. Monitor. Assess. 184 (2), 777-795.

Alve, E., Korsun, S., Schönfeld, J., Dijkstra, N., Golikova, E., Hess, S., Husum, K., Panieri, G., 2016. Foram-AMBI: A sensitivity index based on benthic foraminiferal faunas from North-East Atlantic and Arctic fjords, continental shelves and slopes. Mar. Micropaleontol. 122, 1-12.

Andrieux-Loyer, F., Aminot, A., 2001. Phosphorus forms related to sediment grain size and geochemical characteristics in French coastal areas. Estuar. Coast. Shelf Sci. 52, $617-629$.

Ayadi, N., Aloulou, F., Bouzid, J., 2015. Assessment of contaminated sediment by phosphate fertilizer industrial waste using pollution indices and statistical techniques in the Gulf of Gabes (Tunisia). Arabian J. Geosci. 8 (3), 1755-1767.

Ayadi, N., Zghal, I., Aloulou, F., Bouzid, J., 2016. Impacts of several pollutants on the distribution of recent benthic foraminifera: the southern coast of Gulf of Gabes, Tunisia. Environ. Sci. Pollut. Res. 23 (7), 6414-6429.
Aylagas, E., Borja, A., Tangherlini, M., Dell'Anno, A., Corinaldesi, C., Michell, C.T., Irigoien, X., Danovaro, R., Rodríguez-Ezpleta, N., 2017. A bacterial community-based index to assess the ecological status of estuarine and coastal environments. Mar. Pollut. Bull. 114, 679-688.

Barras, C., Jorissen, F.J., Labrune, C., Andral, B., Boissery, P., 2014. Live benthic foraminiferal faunas from the French Mediterranean Coast: towards a new biotic index of environmental quality. Ecol. Ind. 36, 719-743.

Ben Alaya, M.B., Saidi, S., Zemni, T., Zargouni, F., 2014. Suitability assessment of deep groundwater for drinking and irrigation use in the Djeffara aquifers (Northern Gabes, south-eastern Tunisia). Environ. Earth Sci. 71 (8), 3387-3421.

Ben Aoun, Z., Farhat, F., Chouba, L., Hadj Ali, M.S., 2007. Investigation in possible chemical pollution of the Bougraha lagoon, south of Tunisia, by chemical wastes. Bulletin Institut national scientifique et technique d'Océanographie et de Pêche Salammbô 34, 119-127.

Ben Brahim, M., Hamza, A., Hannachi, I., Rebai, A., Jarboui, O., Bouain, A., Aleya, L. 2010. Variability in the structure of epiphytic assemblages of Posidonia oceanica in relation to human interferences in the Gulf of Gabes, Tunisia. Mar. Environ. Res. 70 (5), 411-421.

Ben Mustapha, K., Hattour, A., 2015. Le couvert végétal marin du golfe de Gabes: État des lieux, intérêt et bénéfices, in: Proceedings of the conference. Les journées de la biodiversité et de la biosécurité aux services de développement durable, Djerba, pp. 152

Ben Mustapha, K., Hattour, A., Mhetli, M., El Abed, A., Tritar, B., 1999. Bionomie des étages infra et circalittoral du golfe de Gabès. Bulletin Institut national scientifique et technique d'Océanographie et de Pêche Salammbô 26, 5-48.

Bergamaschi, A., Tsamakis, E., Keil, R.G., Eglinton, T.I., Montluçon, D.B., Hedges, J.I. 1997. The effect of grain size and surface area on organic matter, lignin and carbohydrate concentration, and molecular compositions in Peru Margin sediments. Geochim. Cosmochim. Acta 61, 1247-1260.

Birk, S., Bonne, W., Borja, A., Brucet, S., Courrat, A., Poikane, S., Solimini, A., van de Bund, W., Zampoukas, N., Hering, D., 2012. Three hundred ways to assess Europe's surface waters: an almost complete overview of biological methods to implement the Water Framework Directive. Ecol. Ind. 18, 31-41.

Borja, A., Franco, J., Pérez, V., 2000. A marine biotic index to establish the ecological quality of soft-bottom benthos within European estuarine and coastal environments. Mar. Pollut. Bull. 40 (12), 1100-1114.

Borja, A., Chust, G., Muxika, I., 2019. Forever young: The successful story of a marine biotic index. Adv. Mar. Biol. 82, 93-127.

Bouchet, V., Alve, E., Rygg, B., Telford, R.J., 2012. Benthic foramnifera provide a promising tool for ecological quality assessment of marine waters. Ecol. Ind. 23, 66-75.

Bouchet, V., Frontalini, F., Goberville, E., 2018. Benthic foraminifera to Ecological Quality Statuses in Italian transitional waters. Ecol. Ind. 84, 130-139.

Carnahan, E.A., Hoare, A.M., Hallock, P., Lidz, B.H., Reich, C.D., 2009. Foraminiferal assemblages in Biscayne Bay, Florida, USA: Responses to urban and agricultural Influence in a subtropical estuary. Mar. Pollut. Bull. 59, 221-233.

Chandoul, I.R., Bouaziz, S., Dhia, H.B., 2015. Groundwater vulnerability assessment using GIS-based DRASTIC models in shallow aquifer of Gabes North (South East Tunisia). Arabian J. Geosci. 8 (9), 7619-7629.

Chao, A., Shen, T.-J., 2003. Nonparametric estimation of Shannon's index of diversity when there are unseen species in sample. Environ. Ecol. Stat. 10, 429-443.

Chen, C.A., Soo, C.L., Balsamo, M., Semprucci, F., 2018. An approach based on nematode descriptors for the classification of ecological quality (EcoQ) of the Malaysian coasts. Mar. Biodivers. 48 (1), 117-126.

Chesher, R.H., 1975. Biological Impact of a Large-Scale Desalination Plant at Key West, Florida. Elsevier Oceanography Series 12, 99-153.

Chouba, L., Mzoughi-Aguir, N., 2006. Trace metals (Cd, Pb, Hg) and total hydrocarbons in superficial sediments from the coast of Gabes Gulf. Bulletin de l'Institut National des Sciences et Technologies de la Mer 33, 93-100.

Cimerman, F., Langer, M.R. (1991). Mediterranean Foraminifera Slovenska Akademija Znanosti in Umetnosti, 33 (Ljubljana), pp. 118.

Cisse, L., Mrabet, T., 2004. World Phospate Production: Overview and Prospects. Phosph. Res. Bull. 15, 21-25.

Dale, V.H., Beyeler, S.C., 2001. Challenges in the development and use of ecological indicators. Ecol. Ind. 1, 3-10.

Darmoul, B., 1988. Pollution dans le golfe de Gabès (Tunisie). Bilan de six années de surveillance (1976-1981). Bull. Inst. Natn. Scient. Tech. Océanogr. Pêche, Salammbô $15,61-83$.

Darmoul, B., Hadj-Ali, M., Vitiello, P., 1980. Effets des rejets industriels de la région de Gabès (Tunisie) sur le milieu marin récepteur. Bulletin Institut national scientifique et technique d'Océanographie et de Pêche Salammbô 7, 5-61.

De Gaillande, D., 1970a. Note sur les peuplements de la zone centrale du golfe de Gabès (Campagne Calypso, 1965). Tethys 2 (1), 131-138.

De Gaillande, D., 1970b. b Peuplements benthiques de l'herbier de Posidonia oceanica (Delile), de la pelouse à Caulerpa prolifera Lamouroux et du large du golfe de Gabes. Téthys 2 (2), 373-383.

Dimiza, M.D., Triantaphyllou, M.V., Koukousioura, O., Hallock, P., Simboura, N., Karageorgis, A.P., Papathanasiou, E., 2016. The Foram Stress Index: A new tool for environmental assessment of soft-bottom environments using benthic foraminifera. A case study from the Saronikos Gulf, Greece, Eastern Mediterranean. Ecol. Indicat. 60, 611-621.

Einav, R., Harussi, K., Perry, D., 2003. The footprint of the desalination processes on the environment. Desalination 152 (1-3), 141-154.

El-Geziry, T.M., Bryden, I.G., 2010. The circulation pattern in the Mediterranean Sea: issues for modeller consideration. J. Operat. Oceanogr. 3, 39-46.

El Kateb, A., 2018. Lesser Syrtis (South of Tunisia): Phosphate industry contamination assessment using a a multidisciplinary approach. PhD Dissertation, University of 
Fribourg, pp. 273.

El Kateb, A., Stalder, C., Neururer, C., Pisapia, C., Spezzaferri, S., 2016. Correlation between pollution and decline of Scleractinian Cladocora caespitosa (Linnaeus, 1758) in the Gulf of Gabes. Heliyon 2 (11) e00195.

El Kateb, A., Stalder, C., Neururer, C., Fentimen, R., Spangenberg, J.E., Spezzaferri, S., 2018a. Distribution of benthic foraminiferal assemblages in the transitional environment of the Djerba lagoon (Tunisia). Swiss J. Geosci. 1-18. https://doi.org/10. 1007/s00015-018-0300-0).

El Kateb, A., Stalder, C., Rüggeberg, A., Neururer, C., Spangenberg, J.E., Spezzaferri, S., 2018b. Impact of industrial phosphate waste discharge on the marine environment in the Gulf of Gabes (Tunisia). PLoS ONE 13 (5) e0197731.

El Lakhrach, H., Hattour, A., Jarboui, O., El Hasni, K., Ramos-Esplá, A.A., 2012. Spatial distribution and abundance of the megabenthic fauna community in Gabes Gulf (Tunisia, eastern Mediterranean Sea). Mediterr. Mar. Sci. 13 (1), 12-29.

El Zrelli, R., Courjault-Radé, P., Rabaoui, L., Castet, S., Michel, S., Bejaoui, N., 2015. Heavy metal contamination and ecological risk assessment in the surface sediments of the coastal area surrounding the industrial complex of Gabes city, Gulf of Gabes SE Tunisia. Mar. Pollut. Bull. 101 (2), 922-929.

El Zrelli, R., Courjault-Radé, P., Rabaoui, L., Daghbouj, N., Mansour, L., Balti, R., Castet, S., Attia, F., Michel, S., Bejaoui, N., 2017. Biomonitoring of coastal pollution in the Gulf of Gabes (SE, Tunisia): use of Posidonia oceanica seagrass as a bioindicator and its mat as an archive of coastal metallic contamination. Environ. Sci. Pollut. Res. 24 (28), 22214-22225.

El Zrelli, R., Rabaoui, L., Alaya, M.B., Daghbouj, N., Castet, S., Besson, P., Michel, S. Bejaoui, N., Courjault-Radé, P., 2018. Seawater quality assessment and identification of pollution sources along the central coastal area of Gabes Gulf (SE Tunisia): evidence of industrial impact and implications for marine environment protection. Mar. Pollut. Bull. 127, 445-452.

Fernández-Torquemada, Y., Sánchez-Lizaso, J.L., 2005. Effects of salinity on leaf growth and survival of the Mediterranean seagrass Posidonia oceanica (L.) Delile. J. Exp. Mar. Biol. Ecol. 320 (1), 57-63.

Francescangeli, F., Du Chatelet, E.A., Billon, G., Trentesaux, A., Bouchet, V.M.P., 2016. Palaeoecological quality status based on foraminifera of Boulogne-sur-Mer harbour (Pas-deCalais, Northeastern France) over the last 200 years. Mar. Environ. Res. 117, 32-43.

acia, E., Invers, O., Manzanera, M., Ballesteros, E, Romero, J., 2007. Impact of the brine from a desalination plant on a shallow seagrass (Posidonia oceanica) meadow. Estuar. Coast. Shelf Sci. 72 (4), 579-590.

argouri, D., Azri, C., Serbaji, M.M., Jedoui, Y., Montacer, M., 2011. Heavy metal concentrations in the surface marine sediments of Sfax Coast Tunisia. Environ. Monitor. Assess. 175 (1-4), 519-530.

GEREP-Environment, 2007. Etude d'impact dur l'environnement de l'usine projetée d'acide phosphorique Tifert dans le site de la Skhira. pp. 239.

Guetat, F., Sellem, F., Akroui, F., Brahim, M., Atoui, A., Ben Romdhane, M.S., Daly Yahia, M.N., 2012. Etat environmental de la lagune de Boughrara et ses alentours deux ans après les travaux d'amenagement et d'élargissement du pont d'El Kantara. Bulletin Institut national scientifique et technique d'Océanographie et de Pêche Salammbô 39, 149-160.

Guillaumont, B., Ben Mustapha, S., Ben Moussa, H., Zaouali, J., Soussi, N., Ben Mammou, A., Cariou, C., 1995. Pollution impact study in Gabes Gulf (Tunisia) using remote sensing data. Mar. Technol. Soc. J. 29 (2), 46-58.

allock, P., Lidz, B.H., Cockey-Burkhard, E.M., Donnelly, K.B., 2003. Foraminifera as bioindicators in coral reef assessment and monitoring: the FORAM index. Environ. Monit. Assess. 81 (1-3), 221-238.

attour, A., Mustapha, Ben, 2013. Le couvert végétal marin du golfe de Gabès:

Cartographie et réseau de surveillance de l'herbier de Posidonie. Institut National des Sciences et des Technologies de la Mer, Tunis, pp. 164.

Heink, U., Kowarik, B., 2010. What are indicators? On the definition of indicators in ecology and environmental planning. Ecol. Ind. 10, 584-593.

ottinger, L., Halicz, E., Reiss, Z., 1993. Recent foraminifera from the Gulf of Aqaba, Red Sea. Akademija Znanosti in Umetnosti, Classi IV: Historia naturalis, 33. Ljubljana, Slovakia, pp. 179.

Husson, F. Josse, J., Le, S., Mazet, J., 2019. "Package 'FactoMineR'.” Package FactorMineR (2019).

Jorissen, F., Nardelli, M.P., Almogi-Labin, A., Barras, C., Bergamin, L., Bicchi, E., El Kateb, A., Ferraro, L., McGann, M., Morigi, C., Romano, E., Sabbatini, Schweizer, M., Spezzaferri, S., 2018. Developing Foram-AMBI for biomonitoring in the Mediterranean: Species assignments to ecological categories. Mar. Micropaleontol. 140, 33-45.

Kassambara, A., Mundt., F., 2017. "Package 'factoextra'." Extract and visualize the results of multivariate data analyses, 76.

Kharroubi, A., Gargouri, D., Baati, H., Azri, C., 2012a. Assessment of sediment quality in the Mediterranean Sea-Boughrara lagoon exchange areas (southeastern Tunisia): GIS approach-based chemometric methods. Environ. Earth Sci. 184, 4001-4014.

Kharroubi, A., Gzam, M., Jedoudi, Y., 2012b. Anthropogenic and natural effects on the water and sediments qualities of costal lagoons: case of the Boughrara Lagoon (Southeast Tunisia). Environ. Earth Sci. 67, 1061-1067.

Langer, M.R., 1993. Epiphytic foraminifera. Mar. Micropaleontol. 20 (3-4), 235-265.

Lakhan, V.C., Cabana, K., LaValle, P.D., 2003. Relationship between grain size and heavy metals in sediments from beaches along the coast of Guyana. J. Coastal Res. 19, 600-608.

Le Danois, E., Ranson, G., du Baty, R.R., 1925. Recherches sur les fonds chalutables des côtes de Tunisie: croisière du chalutier "Tanche" en 1924. Office Scientfique et Technique des Peches Maritimes, Mémoires, n. 3. Blondel La Rougery, Paris, pp. 56.

Loeblich, A.R., Tappan, H., 1994. Foraminifera of the Sahul Shelf and Timor Sea. Cushman Foundation for Foraminiferal Research Special Publication n.31, pp. 661.

Martínez-Colón, M., Hallock, P., Green-Ruíz, C., 2009. Strategies for using shallow-water foraminifera as bioindicators of potentially toxic elements: a review. J. Foramin. Res. 39 (4), 278-299.

Mateu-Vicens, G., Khokhlova, A., Sebastián-Pastor, T., 2014. Epiphytic foraminiferal indices as bioindicators in Mediterranean seagrass meadows. J. Foramin. Res. 44 (3), 325-339.

Melis, R., Celio, M., Bouchet, V.M., Varagona, G., Bazzaro, M., Crosera, M., Pugliese, N., 2019. Seasonal response of benthic foraminifera to anthropogenic pressure in two stations of the Gulf of Trieste (northern Adriatic Sea, Italy): the marine protected area of Miramare versus the Servola water sewage outfall. Mediterran. Mar. Sci. 20 (1), 120-141.

Messaoudi, I., Deli, T., Kessabi, K., Barhoumi, S., Kerkeni, A., Saïd, K., 2009. Association of spinal deformities with heavy metal bioaccumulation in natural populations of grass goby, Zosterisessor ophiocephalus Pallas, 1811 from the Gulf of Gabès (Tunisia). Environ. Monit. Assess. 156 (1-4), 551.

Milliman, J.D., 1994. Organic matter content in US Atlantic continental slope sediments: decoupling the grainsize factor. Deep Sea Research Part II: Topical Studies in Oceanography. 41(4 \pm 6$)$ : 797-808.

Milker, Y., Schmiedl, G., 2012. A taxonomic guide to modern benthic shelf foraminifera of the western Mediterranean Sea. Palaeontol. Electronica 15 (2), 1-134.

Mkawar, S., Azri, C., Kamoun, F., Montacer, M., 2007. Impact sur les biophases marines des rejets anthropiques, notamment des métaux lourds rejetés sur le littoral nord de la ville de Sfax (Tunisie). Techniques Sciences Méthodes 10, 71-85.

Moore, J.R., Ramamoorthy, S.S., 1984. Heavy Metals in Natural Waters. Springer Verlag, New York.

Nixon, S.W., 1995. Coastal marine eutrophication: a definition, social causes, and future concerns. Ophelia 41 (1), 199-219.

Othmani, A., Béjaou, B., Chevalier, C., Elhmaidi, D., Devenon, J.-L., Aleyae, L., 2017. High-resolution numerical modelling of the barotropic tides in the Gulf of Gabes, eastern Mediterranean Sea (Tunisia). J. Afr. Earth Sci. 129, 224-232.

Parmar, T.K., Rawtani, D., Agrawal, Y.K., 2016. Bioindicators: the natural indicator of environmental pollution. Front. Life Sci. 9 (2), 110-118.

Pérez-Domingo, S., Castellanos, C., Junoy, J., 2008. The sandy beach macrofauna of Gulf of Gabes (Tunisia). Mar. Ecol. 29 (s1), 51-59.

Pergent, G., Gerakaris, V., Sghaier, Y.R., Zakhama-Sraier, R., Fernández Torquemada, Y., Pergent-Martini, C., 2016. Posidonia oceanica (errata version published in 2018). The IUCN Red List of Threatened Species 2016: e.T153534A135156882. Downloaded on 19 December 2018.

Pomar, L., Baceta, J.I., Hallock, P., Mateu-Vicens, G., Basso, D., 2017. Reef building and carbonate production modes in the west-central Tethys during the Cenozoic. Mar. Pet. Geol. 83, 261-304.

Rabaoui, L., Balti, R., Zrelli, R., Tlig-Zouari, S., 2014. Assessment of heavy metals pollution in the Gulf of Gabes (Tunisia) using four mollusk species. Mediterran. Mar. Sci 15 (1), 45-58.

Core Team, R., 2018. R: A language and environment for statistical computing. R Foundation for Statistical Computing, Vienna, Austria.

Romero, J., Martínez-Crego, B., Alcoverro, T., Pérez, M.M., 2007. A multivariate index based on the seagrass Posidonia oceanica (POMI) to assess ecological status of coasta waters under the Water Framework Directive (WFD). Mar. Pollut. Bull. 55 (1-6), 196-204.

Sen Gupta, B.K., 2013. The roots of environmental micropalaeontology: early inquiries into modern foraminiferal distributions, in: Bowden, A.J., Gregory, F.J., Henderson, A.S. (Eds.), Landmarks in Foraminiferal Micropalaeontology: History and Development. The Micropalaeontological Society, Special Publications. Geological Society, London, pp. 181-191.

Schönfeld, J., Alve, E., Geslin, E., Jorissen, F., Korsun, S., Spezzaferri, S., Members of the FOBIMO group, 2012. The FOBIMO (FOraminiferal BIo-MOnitoring) initiative Towards a standardised protocol for soft-bottom benthic foraminiferal monitoring studies. Mar. Micropaleontol. 94, 1-13.

Schorer, M., 1997. Pollutant and organic matter content in sediment particle size fractions." IAHS Publications Series of Proceedings and Reports of the International Association of Hydrological Sciences, 243, pp. 59-68.

Simboura, N., Zenetos, A., 2002. Benthic indicators to use in ecological quality classification of Mediterranean soft bottom marine ecosystems, including a newbiotic index. Mediterr. Mar. Sci. 3, 2, 77-111.

Shannon, C.E., Weaver, W., 1963. The Mathematical Theory of Communication. The University of Illinois Press, Illinois.

Troupin, C., Sirjacobs, D., Rixen, M., Brasseur, P., Brankart, J.M., Barth, A., AlveraAzcárate, A., Capet, A., Ouberdous, M., Lenartz, F., Toussaint, M.E., Beckers, J.M., 2012. Generation of analysis and consistent error fields using the Data Interpolating Variational Analysis (Diva). Ocean Model. 52-53, 90-101. https://doi.org/10.1016/ j.ocemod.2012.05.002.

Tyson, R.V., 1995. Abundance of organic matter in sediments: TOC, hydrodynamic equivalence, dilution and flux effects. In: Tyson, R.V. (Ed.), Sedimentary organic matter. Springer, Dordrecht, pp. 81-118.

Wali, A., Colinet, G., Khadhraoui, M., Ksibi, M., 2013. Trace metals in surface soil contaminated by release of phosphate industry in the surroundings of Sfax-Tunisia. Environ. Res. Eng. Manage. 3 (65), 20-30.

Wali, A., Colinet, G., Ksibi, M., 2014. Speciation of heavy metals by modified BCR sequential extraction in soils contaminated by phosphogypsum in Sfax, Tunisia. Environ. Res. Eng. Manage. 4 (70), 14-26.

Wei, Taiyun, Simko, Viliam, Levy, Michael, Xie, Yihui, Jin, Yan, Zemla, Jeff, 2017. Package 'corrplot'. Statistician 56, 316-324.

Zaouali, J., 1993. Les peuplements benthiques de la petite Syrte, golfe de Gabès-Tunisie. Résultats de la campagne de prospection du mois de juillet 1990. Marine Life, 3, 1-2, $47-60$. 